\title{
Bevanda asiatica: Scholarly Exchange between the Ottomans and Europeans on Coffee
}

Duygu Yıldırm*

Bevanda asiatica: Osmanlılar ve Avrupalılar Arasında Kahve Hakkında Bilgi Alışverişleri Öz - Bu makale, Luigi Ferdinando Marsigli'nin gözardı edilmiş eseri, Bevanda asiatica'ya (1685) odaklanarak, geç onyedinci yüzyılda Osmanlılar ve Avrupalılar arasındaki bilgi alışverişini incelemektedir. Bevanda asiatica, hem Hezarfen Hüseyin'in kahve üzerine yazdığı ansiklopedi maddesine, hem de Marsigli'nin Osmanlı topraklarında bir doğa bilimci ve köle-aşçı olarak yaşadığı deneyimlere dayanmaktadır. Marsigli, Hezarfen'in empirik açıdan sunulan kahve bitkisi tasvirini, kahve üzerine yazılmış “en orjinal kaynak" olarak atfeder. Marsigli'nin neden ve nasıl Hezarfen'in metnini seçtiğini inceleyerek bu makale erken modern dönemdeki kültürlerarası bilgi alışverişi pratiklerine ışık tutmaktadır.

Anahtar kelimeler: kahve, erken modern (Yeniçağ), Marsigli, Hezarfen, bilgi alışverişi, doğa tarihi, tıp tarihi, bilim tarihi.

"Come here, let us look into the mirror together." I looked, and under the raw light of the lamp saw once again how much we looked alike. ... The two of us were one! Now, this appeared to me to be an obvious truth. ... Then he said he had captured my soul ... Now, whatever I was thinking, he said he knew about, and whatever I knew, he was thinking of.

(Orhan Pamuk, The White Castle, 90-1)

* Stanford University.

Acknowledgments: I would like to thank Paula Findlen, Alan Mikhail, Robert Morrison, and Shahzad Bashir for their insightful comments. I am also grateful to Anna Toledano and Emanuela Pergolizzi for their feedback. This project was funded by the SSRC's international dissertation research fellowship (IDRF, 2017-2018). 
Despite its widespread, yet controversial usage across the Ottoman Empire, coffee continued to be a mysterious substance for Europeans until the late seventeenth century. Knowledge of coffee was so limited in Western Europe that in France some even called coffee meure: mulberry. "The Turkes berry drinke," coffee, was one of the most "strange and outlandish plants" ever known in the theater of plants. ${ }^{2}$ The rise of European interest in coffee was sparked by travel accounts that praised the miraculous effects of coffee, both for those who suffered from various diseases and those who wished to preserve their good health. The first references to coffee in European texts appeared in medical accounts in the sixteenth century, mostly from European learned travelers to the Ottoman Empire. For example, Carolus Clusius's (1526-1609) medical text, Aromatum et simplicium aliquot medica-mentorum apud Indos nascientum historia (1575), which was the first European text to mention coffee, ${ }^{3}$ owed its information on coffee to a naturalist from Padua, Prospero Alpino (1553-1617). Invited by the Venetian consul to Alexandria of Egypt to serve as his personal physician, Alpino arrived in Cairo in 1581. After three years of study of medical traditions as well as the animals and plants of the region, he published De plantis Aegypti (Venice, 1591) which includes a section on "Bon," the Arabic word for coffee bean. Alpino's observations in Egypt made his account one of the main references for later works on coffee in European scholarship.

Yet, Alpino's description of "bon" was not sufficient for the botanical classification of the newly discovered coffee plant. During the seventeenth century, as drinking coffee became increasingly popular in Western Europe, European naturalists began to face a dilemma: they had not seen a live specimen of the coffee plant, only the beans from which the drink was made. Likewise, new medical debates on the effects of hot beverages and fears of hypochondria brought about

1 On coffee in the early modern era, see Ralph S. Hattox, Coffee and Coffeehouses: The Origins of a Social Beverage in the Medieval Near East (Seattle: WA, 1985), Brian Cowan, The Social Life of Coffee: The Emergence of the British Coffeehouse (New Haven: Yale University Press, 2005), Robert Liberles, Jews Welcome Coffee: Tradition and Innovation in Early Modern Germany (Waltham: MA, 2012), Emma Spary, Eating the Enlightenment: Food and the Sciences in Paris, 1650-1760 (Chicago: University of Chicago Press, 2012), 51-145, Julia Landweber, "'This Marvelous Bean': Adopting Coffee into Old Regime French Culture and Diet," French Historical Studies, 38 (2015): 193-223.

2 John Parkinson, Theatrum Botanicum (London, 1640), 1622-23.

3 On Carolus Clusius, see Florike Egmond, The World of Carolus Clusius: Natural History in The Making, 1550-1610 (London: Pickering \& Chatto, 2010). 
a profound need for a precise classification of the plant. Despite this interest on one side, there were also some physicians who were not in favor of new beverages. Debates on coffee escalated so much that some famous naturalists such as Francesco Redi (1626-1697) claimed that they would prefer poison to a cup of coffee. ${ }^{4}$ This controversy over coffee as well as his own deep interest led Luigi Ferdinando Marsigli, a Bolognese naturalist (1658-1730), to pen his treatise, Bevanda Asiatica, brindata all'eminentissimo Buonvisi, Nunzio Apostolico (Vienna: Van Ghelen, 1685), with the hope that "everyone will stop bothering" him with their unceasing questions about coffee. ${ }^{5}$

Dedicated to Cardinal Francesco Buonvisi (1626-1700), Bevanda asiatica is among the first European books on coffee, and it is the first Italian treatise on coffee written in the vernacular. ${ }^{6}$ It holds a unique place among early modern books on coffee since it includes a contemporary Ottoman text on coffee. These two narrations, Marsigli's own text in Italian and Hezarfenn Hüseyin's (d. 1692) encyclopedic entry on coffee in Ottoman Turkish, were published together in Bevanda asiatica. Marsigli acquired this Ottoman text himself from Hezarfenn in Istanbul, where they first met in 1679.

This textual, as well as physical, encounter between European and Ottoman intellectual worlds begs the question of how and why Marsigli selected Hezarfenn's text on coffee as an authority on the usage and medicinal benefits of the beverage in Bevanda asiatica. I argue that through his treatise on coffee, Marsigli puts forth the idea that one can reach a certain truth through conversations with different individuals regardless of religion, but only if each person is engaged in a shared enterprise of trying to understand nature. For Marsigli, who aimed to revise the humanist discourse on Islam and deepen European understanding of Ottoman culture and society, the possibilities for a more universal understanding of the world seemed to transcend the specificity of time and place, making it possible to acquire well-informed knowledge of other cultures. ${ }^{7}$

4 Francesco Redi, Bacco in Toscana (Firenze: 1685), 310.

5 Luigi Ferdinando Marsigli, Bevanda asiatica (Vienna: 1685), 39.

6 Luigi Rava, Il Conte Marsigli e il Caffé, in Memorie intorno a L. F. Marsili pubblicate nel secondo centenario dalla morte per cura del comitato marsiliano (Bologna: Zanichelli, 1930), 381-357.

7 The studies on the origins of "Turks," mostly by Italian humanist scholars in the fifteenth and sixteenth centuries, changed dramatically in the seventeenth century with the rise of Orientalist scholars in Western Europe. See Alastair Hamilton and Francis Richard, 
This article intervenes in distinct bodies of scholarly literature. First, it contributes to the understudied history of knowledge exchanges between the Ottomans and Europeans in the seventeenth century. The classic accounts of tıbb-ı cedid (new medicine) have explored the arrival of Paracelsian medicine to the Ottoman Empire during 1650 and 1730 from the leitmotif of westernization. In the same vein, former scholarship has extensively focused on one-dimensional knowledge transfer from Europe. Instead, this article offers a new framework by shifting focus away from comparisons between distinct intellectual cultures to an emphasis on scholarly engagements. By examining the changing patterns in medicinal knowledge in the Ottoman Empire, this article shows how scholarly engagements became possible when scholars negotiated over a common, agreedupon goal. I unearth how Hezarfenn adopted Paracelsian medicine and revised available Islamic and European pharmacological knowledge according to the idea of experience (tecrübe) in his medicinal encyclopedia. Hezarfenn's interest in contemporary European medicine and the idea of empirical evidence made his compendium appealing to Marsigli, particularly Hezarfenn's entry on coffee.

Lastly, this article approaches the curious case of coffee from the perspective of the history of knowledge. Existing works exclusively define coffee either as a component of material culture or of coffeehouses through a Habermasian public sphere. ${ }^{8}$ Yet, coffee was also an object of knowledge. While coffee as an exotic commodity gained popularity in Europe, so did Ottoman manuscripts on coffee. European physicians, naturalists, merchants, and Orientalists hunted for Ottoman sources on coffee to forge their own authoritative knowledge on this new substance. Yet, these knowledge-claims over medical authority have not received any attention in recent studies on the Ottoman Empire. Instead, writing

André du Ryer and Oriental Studies in Seventeenth-Century France (Oxford: Oxford University Press, 2004), Nancy Bisaha, Creating East and West: Renaissance Humanists and The Ottoman Turks (Philadelphia: University of Pennsylvania Press, 2006), Margaret Meserve, Empires of Islam in Renaissance Historical Thought (Cambridge, Mass.: Harvard University Press, 2008), Nicholas Dew, Orientalism in Louis XIV's France (Cambridge: Cambridge University Press, 2009), Alexander Bevilacqua, The Republic of Arabic Letters: Islam and the European Enlightenment (Cambridge, Mass.: Harvard University Press, 2018).

8 Jürgen Habermas, The Structural Transformation of the Public Sphere: An Inquiry into a Category of Bourgeois Society, trans. Thomas Burger (Cambridge: MIT Press, 1989). Brian Cowan suggests that the coffeehouse culture of early modern Europe is a component of global history; see Brian Cowan, The Social Life of Coffee, the Emergence of the British Coffeehouse (New Haven: Yale University Press, 2005). 
on controversial substances such as coffee and tobacco has addressed the conflict, or negotiation, between the Ottoman state and the public sphere rather than rival forms of knowledge. ${ }^{9}$ I shift this emphasis to the history of coffee itself as a story set between textual exchanges and medicinal knowledge in the early modern world.

\section{Marsigli in Ottoman Lands}

When Luigi Ferdinando Marsigli came to Istanbul in 1679 with the new Venetian ambassador, Pietro Civrani, he was already aware that this journey would be more than an official mission. ${ }^{10}$ As a military entrepreneur and naturalist involved in projects of war and peace, Marsigli originally aimed to observe the Bosporus for strategic reasons. Yet as he spent time in the Ottoman world, his interest expanded into a lifelong fascination with it and a steady stream of publications and projects on both the Ottomans and Ottoman natural landscapes. ${ }^{11}$ At

9 Cemal Kafadar, "How dark is the history of the night, how black the story of coffee, how bitter the tale of love: The changing measure of leisure and pleasure in early modern Istanbul," Medieval and Early Modern Performance in the Eastern Mediterranean, eds. Arzu Öztürkmen and Evelyn Birge Vitz (Turnhout: Brepols, 2014), 243-269, Eminegül Karababa and Güliz Ger, "Early modern Ottoman coffeehouse culture and the formation of the consumer subject," Journal of Consumer Research 37.5 (2010): 737-760. Also see Alan Mikhail, "The Heart's Desire: Gender, Urban Space and the Ottoman Coffeehouse," Ottoman Tulips, Ottoman Coffee, ed. Dana Sajdi (New Yorks: I.B. Taruris, 2007), 138-139. For a comparative perspective with Safavid Isfahan, see Farshid Emami, "Coffehouses, Urban Spaces, and the Formation of a Public Sphere in Safavid Isfahan,” Muqarnas 33 No. 1 (2016): 177-220.

10 Most historical works on Luigi Ferdinando Marsigli, the founder of Academy of Sciences of the Institute of Bologna (1715), are in the Italian historiography. See Ettore Rossi, "il Secondo Centenario della Morte di Luigi Ferdinando Marsigli," Oriente Moderno 8 (1931), 415-424. Also see, Raffaella Gherardi (ed.), La Politica, La Scienza, Le Armi: Luigi Ferdinando Marsili e la costruzione della frontier dell'Impero e dell'Europe (Bologna: CLUEB, 2010), and Angelo Varni (ed.), La Scienza delle Armi: Luigi Ferdinando Marsili 1658-1730 (Bologna: Edizioni Pendragon, 2012), Monica Molnar, "Nouva vision degli intellettuali italiani sulla cultura musulmana del Seicento: Giovanni Battista Donado e Luigi Ferdinando Marsigli sulla letteratura e scienza dei Turchi," Nouva Corvina, 24 (2012), pp. 57-70. For a biographical study on Marsigli, see John Stoye, Marsigli's Europe 1680-1730: The Life and Times of Luigi Ferdinando Marsigli, Soldier and Virtuoso (New Haven \& London: Yale University Press, 1994).

11 Marsigli's works related to Ottoman nature include Osservazioni interne al Bosforo Tracio (Rome, 1681). 
the center of this fascination were his relations with leading Ottoman scholars with diverse interests, especially with the polymath Hezarfenn Hüseyin Efendi. In a short period of time, Hezarfenn provided Marsigli with access to a considerable body of knowledge that laid the foundation for his prolific writings on Ottoman history, culture, and nature. At the end of his first sojourn in Istanbul, Marsigli already had enough material and local knowledge to pen books on the military system of the Ottomans, the currents of the Bosporus, and the medicinal uses of coffee. ${ }^{12}$ After this trip, he insisted on the crucial importance of understanding the Ottoman world as represented in influential contemporary Ottoman sources.

A renowned polymath of his time, Hezarfenn Hüseyin Efendi was a native of Cos (Turkish: Istanköy). He completed his education in Istanbul and then served the Ottoman state as a Treasury official. Among other well-known artisans and scholars in Istanbul, such as Köse İbrahim Efendi (d. after 1664), Panayiotis (Panagiotakis) Nikousios (d. 1673), Ebubekir bin Behrâm Dımeşkî (d. 1691), and Alexander Mavrocordatos (d. 1709), Hezarfenn soon stepped into Fazll Ahmed Pasha's patronage. Through the patronage of the grand vizier, Hezarfenn had direct access to European diplomatic networks in the capital. His interest in a variety of subjects, ranging from world history to medicine, and his endeavors to integrate European sources into his historical works led to fruitful scholarly conversations with European residents, such as the well-known scholar of Oriental languages, Antoine Galland (1646-1715). ${ }^{13}$

12 After Marsigli arrived in Istanbul in 1679, diplomatic relations between the Venetian Empire and the Ottoman Porte were suddenly upended and Civrani was recalled by Venetian officials. Underlying reasons for the conflict between Ottoman officials and the Venetian Bailo require further studies into diplomatic records. Giovanni Fantuzzi's bibliographical work on Marsigli, Memorie della vita del Generale co. Luigi Ferdinando Marsigli (Bologna: L. dalla Volpe, impress. dell' Istituto delle scienze 1770), suggests that the Ottoman grand vizier of the period, Merzifonlu Kara Mustafa Pasha (1634/5-1683) possessed great talents and "great ideas," but was an "avaricious man." His greed was said to be so overwhelming it ultimately ruined the Venetian Bailo's ability to enjoy his sojourn in Istanbul, Memorie, 9-10.

13 On Hezarfenn, see V. L. Ménage, "Husayn (Huseyn) Efendi, known as Hezārfenn," Encyclopaedia of Islam, Second Edition, ed. P. Bearman, Th. Bianquis, C.E. Bosworth, E. van Donzel, W.P. Heinrichs (Brill Online, 2016), Heidrun Wurm, Der Osmanische Historiker Huseyn b. Gafer, genant Hezârfenn, und die Istanbuler Gesellschaft in der zweiten Hälfte des 17. Jahrhunderts (Freiburg: Klaus Schwarz, 1971). 
Despite being a central figure in the evolution of new ideas regarding the Ottoman world and Islamic civilization in seventeenth-century Europe, Hezarfenn's knowledge exchange with European scholars in Istanbul remains understudied. Hezarfenn not only engaged in conversations about faith and knowledge with the Europeans, but also recommended manuscripts that matched the scholarly pursuits of these scholars. As a young, ambitious scholar, Marsigli was deeply impressed by Hezarfenn's robust encyclopedic knowledge. Inspired by his Ottoman mentor, Marsigli aimed to refute stereotypical images of the Ottomans in the contemporary Europe. To Marsigli, these unfounded biases stemmed from the fact that Europeans did not know "Oriental languages." On the contrary, he claimed that men interested in science and knowledge both in Istanbul and in the other parts of the empire knew Turkish, Arabic, and Persian very well.

As a knowledge broker between the Ottoman Empire and Europe, Marsigli acknowledged the importance of learning languages and collecting foreign sources of knowledge to build universal libraries. Marsigli claimed in his own work on the history of the Ottomans, Stato Militare dell' Imperio Ottomanno (1732), that Ottomans, just as their European contemporaries, were interested in a wide range of scholarly topics. ${ }^{14}$ Taking pride in his own rich collection of Oriental manuscripts in Bologna, he stressed that his own manuscript collection procured both from the Ottoman urban centers and peripheries also reflected a diversity of topics, from alchemy to moral arts. ${ }^{15}$

Talking about manuscripts led Marsigli to reflect on the perennial question of the absence of a Muslim printing press. He rejected the widespread view among Europeans who associated the lack of the printing press in the Ottoman Empire with prohibitions imposed by Islam. In fact, Marsigli noted, the Ottoman reluctance towards introducing the printing press stemmed from the large number of scribes, reaching to ninety thousand. The vulnerable condition of the scribes, who were at the risk of losing their jobs, was frequently stated to Christians and Jews when they hoped to introduce printing for their own economic profit. ${ }^{16}$

14 Luigi Ferdinando Marsigli, Stato militare dell'Imperio Ottomanno, incremento et decremento del medesimo: L'Etat militaire de l'Empire Ottoman, ses progrès et sa décadence (The Hague, 1732). The book was published in a bilingual Italian and French edition.

15 Marsigli, Stato militare dell'Imperio Ottomanno, 39.

16 Marsigli, Stato militare dell'Imperio Ottomanno, 40. 
Marsigli's efforts as a go-between helped develop grounds for a rapprochement, and in some instances a reconciliation, between Ottoman and European intellectual worlds. His intellectual legacy reached the minds of Enlightenment thinkers such as Voltaire, who similarly complained that, "We are neighbors of the Turks, yet we do not know them. The Count of Marsigli, who lived for so long among them, says that no author has provided true knowledge of their empire, nor of their laws." ${ }^{\prime 17}$ Despite these challenges to acquire empirical evidence about the Ottomans, Marsigli managed to establish his own expertise on the Ottoman world by studying Ottoman nature, culture, religion, and history sometimes as a naturalist, sometimes as a philologist. Even though all of his interactions with Ottoman scholars did not necessarily lead to publications, his observations in his notebooks illustrate how he gradually became a more knowledgeable scholar by adopting eclectic methods.

However, ongoing diplomatic crises often derailed these scholarly interactions in Istanbul. Luigi Ferdinando Marsigli's intentions to carry out projects regarding this "unknown" Ottoman world were jeopardized as he realized that he too would have to return to Venice after a diplomatic dispute between Ottoman and Venetian officials. Leaving Istanbul in August 1680, he passed Adrianople, Philipopolis, Sofia, and Nit on his way home in order to make observations about the landscape. In 1681, he published his work on the Bosphorus, Osservazioni Intorno al Bosforo Tracio, in Rome, which sparked the interest of the members of the Royal Society of London, of which he also became a member in 1690. Despite Marsigli's silence on his specific role in this mission to Istanbul in his writings, he expressly succeeded in using this voyage for his own career plans. When he returned to Venice in the summer of 1681 , he decided to pursue a military career. In the following year, he succeeded in joining the Imperial Army of the Emperor Leopold (1640-1705), which required his participation to the Battle of Vienna (1683) against the Ottomans. This quest, however, ended in misfortune for him: he was wounded, captured, and eventually sold to an Ottoman pasha. He served as a slave in a certain Ahmed Pasha's court near Vienna until his release in March 1684. ${ }^{18}$ Nevertheless, Marsigli was not slow to transform this misfortune into a

17 Voltaire, Commentaire sur l'esprit des loix de Montesquieu (Paris: 1778), para. 13, 25; also quoted in Alexander Bevilacqua, The Republic of Arabic Letters, 176.

18 Luigi Ferdinando Marsigli, Ragguaglio della Schiavitú, ed. Bruno Basile (Roma: Salerno Editrice, 1996), E. Lavorini, La schiavitú sotto i tartari e i turchi del generale Luigi Ferdinando Marsigli (Bologna: Zanichelli, 1931). 
gain, since his own experience with coffee preparation from his enslavement was a timely topic in Bevanda asiatica.

In 1683, the Ottomans failed again in their long-lasting dream of conquering Vienna, but their coffee did conquer the city. Almost concomitantly with Venice and London, Vienna played a crucial role in the emergence of the coffeehouses to which Marsigli also contributed with his Bevanda asiatica. Soon after the Treaty of Karlowitz in 1699, which ended the Ottoman-Habsburg conflict, coffee drinking and coffeehouses became a Europe-wide phenomenon. Published in Vienna only two years after the city's siege by the Ottomans, Bevanda asiatica demonstrates Marsigli's pragmatic attitude towards war. He channeled Europeans' renascent fears of the Ottomans into a new exotic commodity from the Ottoman lands: coffee. In a similar vein, he presented himself as one of the few European experts on coffee due to the empirical, experiential knowledge he gained from his days as a slave-cook. Such cases, in which captivity led to new forms of knowledge and made captives experts on the societies that captured them, was highly common during the early modern era. ${ }^{19}$

Marsigli's duty as a slave was to make coffee for people at the pasha's tent in which coffee was sold: "While I was mechanically serving in his court, I had to practice for many days the art of coffee making in a smoky tent. [...] This duty trained me in the art of coffee making and in observing its various effects, and it was the activity that gave me back my life, since while serving coffee I had met those Bosnians who bought me just in time when I was about to die under the ottoman saber as a punishment for my attempt to escape. ${ }^{20}$ Coffee restored Marsigli to freedom and his former life: "coffee had a great value for me and it is actually right for me to be grateful in exalting its intrinsic qualities."21

Based on his own experiences as a captive, Marsigli had opinions about how to prepare coffee well. In Bevanda asiatica, he presented an elaborate account starting with choosing the right coffee grains, how to roast them, how to boil the coffee powder, and finally how to spice up the taste and serve coffee in majolica

19 Lisa Voigt, Writing Captivity in the Early Modern Atlantic: Circulations of Knowledge and Authority in the Iberian and English Imperial Worlds (Chapel Hill: The University of North Carolina Press, 2009), Daniel Hershenzon, "Towards a connected history of bondage in the Mediterranean: Recent trends in the field," History Compass, 15 (2017), 1-13.

20 Marsigli, Bevanda asiatica, 9.

21 Marsigli, Bevanda asiatica, 10. 
or porcelain ceramics. ${ }^{22} \mathrm{He}$ also gave hints on how to cook coffee and common mistakes made while preparing it, which he "learnt at the cost of being frequently whipped." ${ }^{23}$ The process of preparing pleasant and nourishing coffee was complicated, but it was also necessary knowledge, since a mistake could easily take coffee's strength away as Marsigli indicated. ${ }^{24}$ Not only the botanical knowledge of this exotic plant, but also the way its grain was prepared to be consumed, was highly valuable information for Europeans who desired the best medicinal effects from coffee. Aware of the insufficient information in Europe, Marsigli turned his slavery into a timely opportunity. He was initially forced to learn how to prepare coffee as a slave-cook and he survived because of it. In an opportunistic manner, Marsigli positioned himself as a European fully immersed in Ottoman knowledge of coffee who knew how to prepare coffee in the Turkish fashion. ${ }^{25}$

While not intended as a captivity narrative, Bevanda asiatica reflects the symbolic link Marsigli created among coffee, his captivity, and his failed attempt to escape. In his other account about his days as a slave from July 2, 1683 to March 25, 1684, Marsigli expressed his fears and awe:

The Arab man for whom I was preparing coffee hurt me with the same iron bar with which I used to smash the coffee grains. He hurt me violently and left me there on the brink of dying. A Turk informed me that the following morning a cart would bring me to the place where slaves used to be beheaded. This decision left me with the sadness of having to die without Sacraments and without being able to let those living in my homeland know about how I died. ${ }^{26}$

Marsigli's memories of coffee dating back to the days of his captivity did not keep him from his lifelong pursuit of knowledge about coffee. To Marsigli the captive, coffee was his lifeblood. However, to Marsigli the naturalist, coffee had varying meanings. In fact, the more Marsigli looked at coffee, the more coffee perplexed him. As his confusion went on, he adopted humanist methods of reading and storing information to capture the full meaning of coffee. For example, by notetaking from and partially translating various Ottoman sources on coffee

22 Marsigli, Bevanda asiatica, 39-45.

23 Marsigli, Bevanda asiatica, 40.

24 Marsigli, Bevanda asiatica, 42.

25 Marsigli, Bevanda asiatica, 38.

26 Marsigli, Ragguaglio della Schiavitú, 31. 
and coffeehouses, Marsigli pondered how coffee succeeded in defying copious bans from the sixteenth century onwards in the Ottoman lands. As he read the history of the origins of coffee and coffeehouses, both from popular narratives and chronicles, he connected the Sufi shaykh Abu'l-Hasan Shadhili (d. 1258) to the discovery of coffee. Marsigli also noted how the sultan thought that coffee was a dangerous invention and ordered ships loaded with coffee to be sunk to give a warning to the population. ${ }^{27}$ Uncanny at times, coffee was a sign of resistance for Marsigli. It was closely related to religious heresy, subversion of the state and autonomy. Yet, the ontology of coffee hinged on both its immateriality and materiality. Thus, Marsigli set to work as a naturalist in his Bevanda asiatica in which coffee came into being as an object of empirical enquiry. ${ }^{28}$

\section{A Shared Enterprise: Bevanda asiatica and Tubfetü'l-Erîb}

The title of Marsigli's treatise is curious since it names coffee an "Asiatic beverage." Interestingly enough, another book on coffee was published in the same year with the same title by the French physician and antiquarian Jacob Spon (1647-1685). Since coffee was considered to have been invented in Yemen, Marsigli called coffee an "Asiatic" drink, as most of his contemporary European scholars did. This affiliation reflects European naturalists' perception of the origins of the coffee plant. Ottomans were the consumers of coffee, yet coffee was indigenous to Yemen.

The title page of Bevanda asiatica indicates that this is a work by "Count Luigi Ferdinando Marsigli who narrates the medical history of coffee" (Figure I). Marsigli omits the name of the Ottoman text he consulted, yet it is Hezarfenn Hüseyin's medicinal encyclopedia, Tuhfetü'l-Erîbi'n-Nâfia lìr-Rûhânî ve't-Tabîb ("The skillful, beneficial gift for the spiritual elect and the physician"). ${ }^{29}$

27 Marsigli associates the introduction of coffee to Istanbul with the reign of Selim I (1465-1520). However, it is not clear if he also refers to Sultan Selim on the account of sinking ships.

28 Lorraine Daston, "Introduction: The Coming into Being of Scientific Objects," Biographies of Scientific Objects, ed. Lorraine Daston (Chicago: Chicago University Press, 2000).

29 The completion year of this work is unknown. Only two editions of the manuscript at Istanbul Süleymaniye Library were dated: MS Nuruosmaniye n. 3466 was completed on Şevval 16, 1096 AH (September 15, 1685) and Şehit Ali Paşa nr. 2086 was completed in 1090 AH (1679/80). See Ekmeleddin Ihsanoğlu (ed.), Türkiye Kütüphaneleri İslami Tip Yazmaları Kataloğu Arapça, Türkçe ve Farsça (İstanbul: IRCICA, 1984), 405, Ekmeleddin Ihsanoğlu (ed.), Osmanlı Tibbî Bilimler Literatürü Taribi (İstanbul: ISAR, 2008), 287. 
On page seven, Marsigli for the first time mentions a Turk whose text he included in his own work. Without naming the title, he informs the reader that this Turkish text talks about "the origin, the development, the ripening and the transformation of the fruit of coffee in a suitable state to prepare a beverage out of it." The arguments put forth by this Turk are also shared by others who previously wrote about coffee, Marsigli emphasizes. ${ }^{30}$ Then he gives the name of the Turkish author, Hüseyin Efendi ("Cuseim Efendi") on the same page (Figure II).

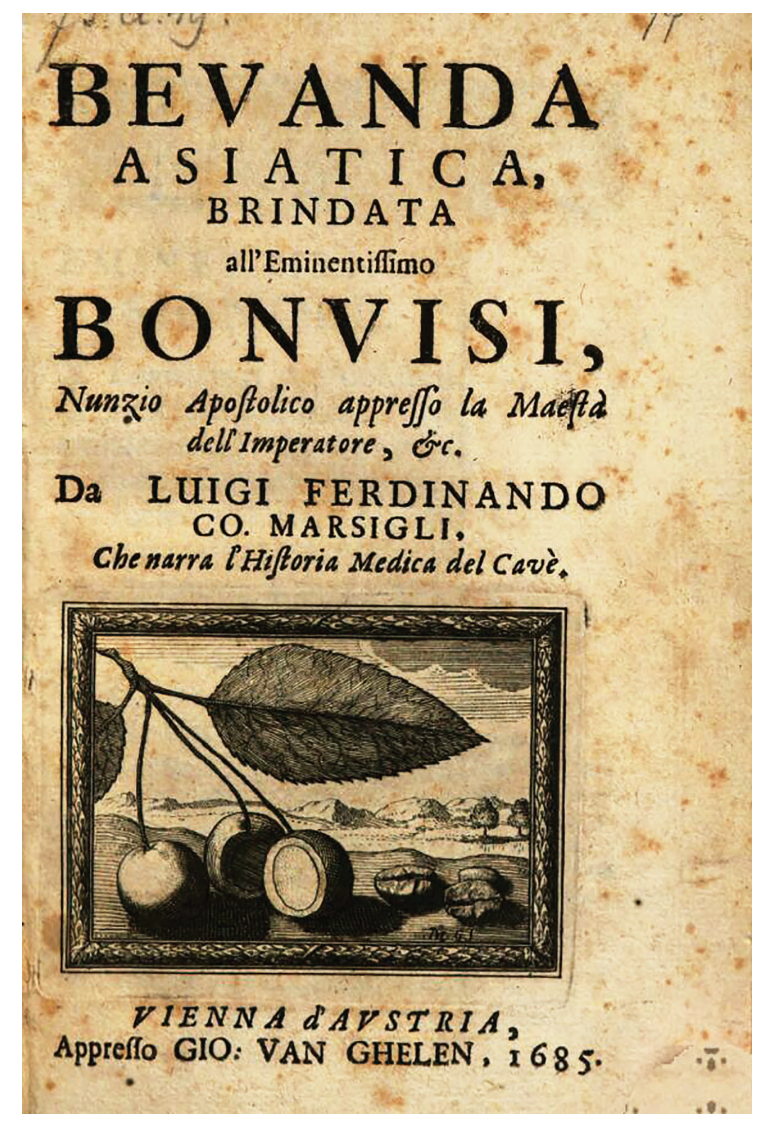

Figures I \& II: Cover page and page 26-27 of Bevanda asiatica (Biblioteca Universitaria di Bologna)

Also see, Feyza Tokat, Hezarfen Hüseyin Efendinin “Tuhfetül-Erîbi’n-Nâfia lìr-Rûhânî ve'tTabîb”, (PhD Diss., Pamukkale University, 2012).

30 Marsigli, Bevanda asiatica, 7. 


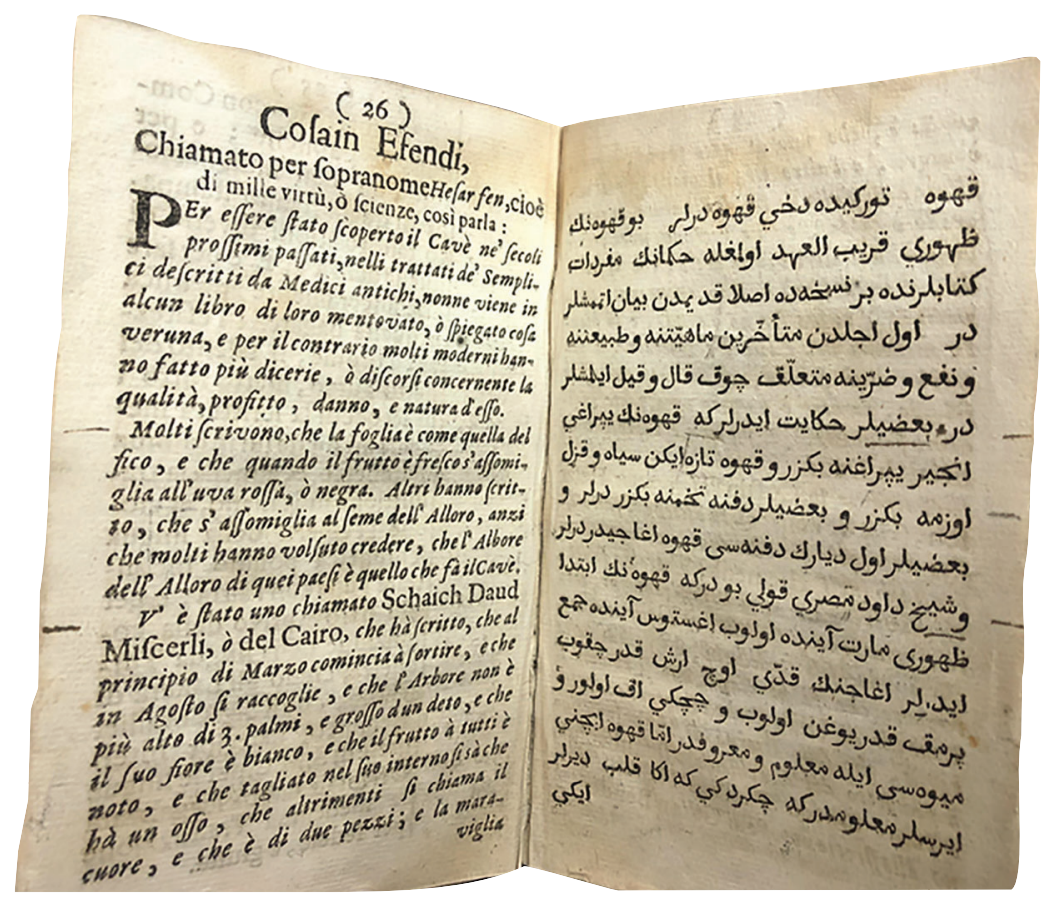

Bevanda asiatica opens with a reference to Plato's Symposium in which a group of notable men Socrates, Eryximachus, Aristophanes, and Agathon toast their drinks while having conversations about philosophy. The inclusion of the Symposium was to familiarize a foreign beverage to the European reader. This motif of friendship and engagement in scholarly discussions becomes central to Marsigli's narrative and reflects Marsigli's close relationship with Hezarfenn in Istanbul. On the first page of Bevanda asiatica, Marsigli directly addressed Cardinal Buonvisi in describing the close relationship between the dinner table and scholarly conversations. He wrote that the most distinguished moral philosophers "thought that there was no better way of displaying their affection than to share with them their food, knowing that Plato, that great man, used to organize feasts that have been memorable until today since they have sparked scholarly discourses which were combined with the delightfulness that the dinner table offers." ${ }^{31}$ Yet, meals do not only stimulate conversations and friendship, since they are also a way of "lifting the burden of preoccupations from the spirit." To this end, Marsigli says that he would like to introduce a foreign beverage to the dinner table of his excellency: "coffee has so many qualities that by consuming

31 Marsigli, Bevanda asiatica, 3. 
it your temperament will receive relief in those parts that sometimes negatively affect your perfect health." ${ }^{32}$ Marsigli assured his readers that the arguments he puts forward "have only been presented by authors who excelled in medicine," even though medicine is not his profession. He also declared that his description of this plant, coffee, is very different than what previous authors have written. Therefore, he stressed, his account on coffee might seem strange to the reader; yet, by including an Ottoman text he received from its own author, Marsigli aimed to make his narrative credible and authentic. ${ }^{33}$ He noted with pride that the original text in Ottoman Turkish is presented with its Italian translation, and the accuracy of his translation was acknowledged by Franz Meninschi, who served as the royal interpreter for Oriental languages. ${ }^{34}$

However, the Ottoman text Marsigli used to give greater credibility to his own narrative was not written by a physician either, since Hezarfenn's main scholarly interest was in history. Why did Marsigli choose this text by an author with no medical training while claiming to present the "medical history of coffee" and its medicinal benefits? The reason was not only because Marsigli thought that "Hezarfenn is the most intelligent mind in the Ottoman Empire," but also because this Ottoman polymath had been to Yemen and observed the coffee plant in its natural environment. Hezarfenn claimed that he had hands-on knowledge of coffee in its own indigenous place, Yemen, where he examined not only the growth of coffee plant and ripening of its beans, but also how to consume coffee in the most effective way. Therefore, Marsigli suggests his readers "listen to what Hezarfenn Hüseyin Efendi says with regards to the origin and the virtues of this fruit," since he explains the truth "in comparison with the lies of other Turks who had written about it, and curious Christians who had given only simplistic accounts, not including the evidence that Hezarfenn had due to his presence in Fertile Arabia as a state official." 35 Marsigli presents Hezarfenn as "a man who has been highly esteemed not only for the position he gained within the Ottoman court and for the exact histories he has written, but also by those Christians, who, like myself, had the privilege to spend time with him in Constantinople's court." ${ }^{\text {"36 }}$ Marsigli’s admiration of Hezarfenn was both personal and intellectual, but did

32 Marsigli, Bevanda asiatica, 5-6.

33 Marsigli, Bevanda asiatica, 7.

34 Marsigli, Bevanda asiatica, 25.

35 Marsigli, Bevanda asiatica, 24-25.

36 Marsigli, Bevanda asiatica, 8. 
not extend to matters of faith. All the Christians who knew him, including Marsigli, fondly remembered his talents and good companionship, yet they mourned the fact that "he died believing in the false Muhammadian religion." ${ }^{37} \mathrm{He}$ was their equal in all but faith.

Hezarfenn's account on coffee, as translated by Marsigli, focuses on the cultivation and the features of the plant as well as its medicinal uses. A comparison between the original entry on coffee in Tuhfetül-Erîbin-Nâfia lìr-Rûhânî ve't-Tabîb in the manuscript and in Marsigli's translation in Bevanda asiatica demonstrates how Marsigli occasionally changed the meaning while consolidating Hezarfenn's textual authority founded in empiricism. Both the original and the translation indicate that coffee was a newly discovered plant and therefore no ancient treaties on medical herbs mentioned it. Yet, modern physicians talked about its essence, benefits, harms, and nature. As an example of these modern physicians, Hezarfenn presents "Sheikh Davud-1 Mısri" (Dâvûd-ı Antâkî, d.1599), who "wrote that the blossom of coffee occurs in March, and it is picked in August when the height of its tree does not exceed three hands and it is not any thicker than a finger. [...] Its nature on the first stage is hot, on the second is dry." In the original Hezarfenn states that "the discourse of Sheikh Davud-1 Misri was completed, [şeyh dãvuduñ kelämı tamām old]], however, this fakir [religious ascetic] stayed in the lands of Yemen for two and half years $[\ldots]$ and saw that plants that yielded coffee beans could be found solely in two regions of Yemen." ${ }^{38}$ In Marsigli's translation, however, this part is different: "This is Sayh Davud-i's opinion. However, I, Hüseyin with the epithet Hesar Fen (of thousands virtues and arts), say that I stayed in the lands of Hiemena." By presenting Dâvûd-1 Antâkî̀s discourse as an "opinion," Marsigli contrasts this indirect knowledge with Hezarfenn's firsthand experience. This word choice in the translation also indicates why Marsigli chose Hezarfenn's account as the most authoritative on coffee. The role Marsigli donned here was intermediary, since he aimed to present himself as a direct conduit to Ottoman learning and knowledge of coffee.

Both in the original and in Marsigli's translation, Hezarfenn underlined how he had actually "experienced" his depictions of coffee himself during his sojourn in Yemen: "This is all I can say about the form, quality, and usage of the coffee plant which I observed and about the taste of the fruit which I ate." ${ }^{39}$ In

37 Marsigli, Bevanda asiatica, 8.

38 Tokat, Tuhfetül-Erîbi’n-Nâfia li'r-Rûhânî ve’t-Tabîb, 77a.

39 Marsigli, Bevanda asiatica, 33. 
the original, Hezarfenn said: "tahrir olundr," meaning that "it was registered."40 Hezarfenn also discussed medicinal benefits and harmful effects stemming from excessive usage of coffee: it "would refresh his humors, balance the excesses of bile, and delight his heart, since its steam would reach his brain. [...] It is especially useful for those who are drunk, and even more for those tiryakis, who consume opium, for travelers, and those who are very tired. [...] There are no doubts that those who drink coffee ten or twelve times a day are likely to become dozy and melancholic. Yet, on the contrary, those who make a moderate use of it will never experience melancholy and will cheer themselves up.”41

In the preface of Tuhfetül-Erîb, Hezarfenn indicated that he compiled his medicinal encyclopedia from different Greek, Persian, Arab, Ottoman, and Latin sources. The main criteria he used in selecting textual sources were based on whether the medicines were already used and proven to be successful (güzide ve mücerreb müfredāt). In this alphabetically arranged encyclopedia, he also included original versions of the loanwords of plants, animals, and other medicinal products as well as their equivalents in Persian, Arabic, Greek, and Latin. Drawing on the hermetic idea of harmony between the human body (microcosmos) and the cosmos (macrocosmos), he stressed that everything in the universe was interconnected. The cosmos was "in constant movement;" therefore his aim was also to capture the differences among plants regarding their growth, seasonal changes, and local climates, as he did in his entry on coffee.

Hezarfenn's main criticism was against physicians of Galenic medicine. For him, their practices to cure diseases were ineffective since they only considered the four humors: blood, yellow bile, black bile, and phlegm. Since they were not able to understand the real causes behind different diseases, their prescriptions were not efficient. ${ }^{42}$ Hence, students of medicine had to know umür-ı tabi'iyye, principles of nature, which is the foundation of medicine. ${ }^{43}$ As for the causes of diseases, Hezarfenn counted them as three: mercury, sulfur, and salt. ${ }^{44}$ Although he did not name it in his encyclopedia, he was referring to Paracelsian medicine.

40 Tokat, Tuhfetül-Erîbi’n-Nâfia lìr-Rûhânî ve't-Tabîb, 77b.

41 Marsigli, Bevanda asiatica, 33.

42 Tokat, Tuhfetül-Erîbi’n-Nâfia lìr-Rûhânî ve't-Tabîb, 11 b.

43 Tokat, Tuhfetül-Erîbin-Nâfia lìr-Rûhânî ve’t-Tabîb, 4b.

44 Tokat, Tuhfetül-Erîbìn-Nâfia lìr-Rûhânî ve't-Tabîb, $10 \mathrm{~b}$. 
Paracelsus's (Theophrastus von Hohenheim, 1493/4-1541) medicine emerged in the time of a new Renaissance interest in the book of nature. Drawing on Christian neo-Platonic and Hermetic philosophy, Paracelsus aimed at replacing Galenic medicine and the conventional explanation of diseases stemming from imbalance of humors with his idea of three principles: mercury, sulfur, and salt ("the three first things"). He claimed that localized malfunctions within the body could be explained through these three principles. The idea of nature was no longer considered a hidden entity, since through observation and experiment one could perceive truth in nature. Bodily experience was a key to certainty about nature. $^{45}$

While Paracelsian medicine maintained its legacy, by the late seventeenth century it was no longer a central way to think about nature in Western Europe. However, Paracelsian medicine received a profound interest in the seventeenthcentury Ottoman Empire during the movement to translate European works. Paracelsus's new medicine ( $t \imath b b-\imath$ cedìd li-Baraqlìsuss) was introduced by the chief physician Ibn Sallum of Aleppo (d. 1669) in his New Chemical Medicine (ȚbbülCedìd al-Kimyevì). Sallum's work was an Arabic translation of collections from Oswald Croll's (1563-1609) Basylica chymica and Daniel Sennert's (1572-1637) De chymicorum. ${ }^{46}$

Hezarfenn did not put Paracelsian medicine forward as the new medicine. He positioned it as the main and only sort of medicine for physicians to use. His preference for Paracelsian medicine over Galenic medicine did not necessarily

45 On Paracelsian medicine, see Allen G. Debus, The Chemical Philosophy: Paracelsian Science and Medicine in the Sixteenth and Seventeenth Centuries (New York: Science History Publications, 1977), Allen G. Debus, Man and Nature in the Renaissance (Cambridge: Cambridge University Press, 1978), Nancy G. Siraisi, Medieval \& Early Renaissance Medicine: An Introduction to Knowledge and Practice (Chicago: University of Chicago Press, 1990).

46 Ibn Sallum's work is known in the current historiography as "New Chemical Medicine," yet al-Kimyä as a term is more relevant to "alchemy." On Paracelsian medicine in the Ottoman Empire, see Nil Sarı and M. Bedizel Zülfikar, "The Paracelsian Influence on Ottoman Medicine in the Seventeenth and Eighteenth Centuries," Transfer of Modern Science and Technology to the Muslim World, ed. Ekmeleddin Ihsanoğlu (Istanbul: IRCICA, 1992), 157-79, Miri Shefer-Mossensohn, "An Ottoman Physician and His Social and Intellectual Milieu: The Case of Salih bin Nasrallah Ibn Sallum," Studia Islamica, 1 (2011): 133-58, Harun Küçük, "New Medicine and the Hikmet-i Tabi'iyye Problematic in Eighteenth Century Istanbul," Texts in Transit in the Medieval Mediterranean, eds. Tzvi Langermann and Robert Morrison (University Park, PA: Penn State Press, 2016), 222-242. 
mean that he discarded earlier Islamic medical authorities, such as Ibn Sina, whose theories were similar to those of Galen. Instead, he merged Islamic pharmacological texts with Paracelsian medicine. His medium for revising pharmacological texts was experience (tecrübe). If any pharmacological account included evidence based on experience, it found its place in Hezarfenn's encyclopedia.

However, for coffee, Hezarfenn thought that there was no reliable empirical information. Although he mentioned Dâvûd-ı Antâkî in his medicinal encyclopedia, he did not acknowledge Antâkîs's account as an absolutely authoritative source on coffee until the previous physician's statements were proven through observation. ${ }^{47}$ This put Hezarfenn's entry on coffee at odds with Orientalist scholar Edward Pococke's (1604-1691) The Nature of the Drink Kauhi, or Coffe, and the Berry of which it is Made, Described by an Arabian Phisitian (Oxford: 1659). ${ }^{48}$ As its title suggests, Pococke's work was an English translation of Antâkî̀s account. Both Hezarfenn and Pococke referred to Antâkî̀s account as an introduction to the perplexing subject of coffee. However, their approaches to Antâkîs text were different. While the English Orientalist was hunting for the oldest manuscript on coffee during the seventeenth century, he evaluated Antâkîs treatise as textual material which provided information regarding the exotic drink of "kauhi." On the other hand, Hezarfenn was more cautious towards the information Antâkî provided. Thus, rather than giving Antâkî absolute authority on coffee, Hezarfenn stressed the necessity of verifying the account on the basis of observation.

Marsigli concluded Bevanda asiatica by stating that the properties of coffee as described by Hezarfenn were in accordance with the discourses by Thomas Willis (1621-1675) and Jérôme Tencke (d. 1687). Thomas Willis, who practiced medicine at Oxford from 1640s to 1650s, associated coffee with sobriety. As a physician particularly interested in melancholy, Willis explained that he frequently prescribed coffee for those who suffered from the effects of the brain. Willis's discourse on the medicinal benefits of coffee was widely cited by other contemporary scholars as well. One of them was Sylvestre Dufour (1622-1687), who referred to Willis in his Traitez nouveaux et curieux du café, du thé et du chocolate (Lyon, 1688) in relation to the benefits of coffee for diseases of the brain (les

47 On Antâkî, see Ayşegül Demirhan Erdemir, "Dâvûd-i Antâkî”, Türkiye Diyanet Vakfı İlâm Ansiklopedisi (DIA), 1994, IX, 26-27.

48 Edward Pococke, The Nature of the Drink Kauhi, or Coffe, and the Berry of which it is Made, Described by an Arabian Phisitian (Oxford: Henry Hall, 1659). 
maladies de la tête)." ${ }^{\not 99}$ Likewise, Marsigli emphasized that both Willis and Tencke, renowned figures in the field of medicine, "agreed that coffee holds the property of clarifying the intellect, dissolving stream, intestinal gas and drying, by penetrating with its volatile parts, the abundant humidity that is usually generated in the parts of the brain." ${ }^{50}$ By referring to them, Marsigli touched on one of the hotly debated subjects in seventeenth-century medicine: hypochondria. While there was no clear distinction between hypochondria and melancholy in the seventeenth century, some physicians from both Europe and the Ottoman Empire named hypochondria a new disease. Some even considered hypochondria a serious epidemic which could only be overcome by "new" medicinal beverages such as coffee and chocolate. ${ }^{51}$ Coffee, however, was the best remedy one could find for many diseases such as hypochondria because of its significant role in digestion. The cause of hypochondria was considered to be related to digestion problems in the stomach. Hydropsy ("hydropisie") which could cause hypochondria, said Dufour, was little known among the Turks since they frequently drank coffee which protected them from it. He explained further that in cities such as London that were quick to adopt coffee, this disease became gradually rarer over the years. ${ }^{52}$

Marsigli prioritized Hezarfenn's account over the other texts on coffee on the grounds of his personal acquaintance with the author and his high esteem for his intellect, as well as Hezarfenn's reliance on empiricism. However, it was also due to a shared methodology in both authors' approaches to knowledge construction. Hezarfenn's rejection of all previous sources mentioning coffee and the emphasis on his own observations in Yemen to where coffee was believed to be indigenous reveals how Hezarfenn aimed to build his own authority over the medicinal history of coffee. His claim about the absence of medical texts on coffee in Tuhfetül-Erîbin is hardly credible, since he was a renowned encyclopedist close to the Ottoman court and the collector of a wide range of manuscripts and books. For Hezarfenn, then, the issue was not really the lack of the availability of any sources on coffee, but the lack of useful texts that were in accordance with his own understanding of coffee.

49 Sylvestre Dufour, Traitez nouveaux et curieux du café, du thé et du chocolate (Lyon, 1688), 176-7.

50 Marsigli, Bevanda asiatica, 46.

51 Yasmin Haskell, "Poetry or Pathology? Jesuit Hypochondria in Early Modern Naples," Early Science and Medicine 12 (2007), 187-213.

52 Dufour, Traitez nouveaux, 129. 
The encyclopedic nature of most of Hezarfenn's works ranging from medicine to history signifies how he aimed to revise available knowledge within the Ottoman Empire according to empiricism. This methodological revision, also shared by his European contemporaries such as Marsigli, reflects the change of a pattern in the Ottoman intellectual world of the seventeenth century. The relationship between Bevanda asiatica and Tuhfetül-Erîbin complicates the history of "cross-cultural knowledge exchanges" in early modernity. Marsigli selected Hezarfenn's text to introduce coffee to Europe not only because of his personal acquaintance with the Ottoman scholar, but also because Hezarfenn adopted a method with which Marsigli was already familiar: Paracelsian medicine and the idea of empiricism. Knowledge exchange between an Ottoman and a European scholar became possible when their intellectual agendas overlapped as well as when they were already familiar with the context from which they would benefit.

\begin{abstract}
Focusing on Luigi Ferdinando Marsigli's neglected treatise, Bevanda asiatica (1685), this article explores knowledge exchanges between the Ottomans and Europeans in the late seventeenth century. Bevanda asiatica was based on Hezarfenn Hüseyin's encyclopedic entry on coffee as well as on Marsigli's own experiences both as a naturalist and as a slave-cook in Ottoman lands. Marsigli stated that Hezarfenn's empirically driven depiction of the coffee plant was "the most original source" on coffee. By analyzing how and why Marsigli selected Hezarfenn's text, this article sheds light onto the practices of cross-cultural knowledge exchanges in the early modernity.
\end{abstract}

Keywords: coffee, early modern, Marsigli, Hezarfenn, knowledge exchange, natural history, history of medicine, history of science.

\title{
Bibliography
}

\section{Primary Sources}

Dufour, Sylvestre: Traitez nouveaux et curieux du café, du thé et du chocolate, Lyon, 1688.

Fantuzzi, Giovanni: Memorie della vita del Generale co. Luigi Ferdinando Marsigli, Bologna: L. dalla Volpe, impress. dell' Istituto delle scienze, 1770.

Hezarfenn Hüseyin: Tuhfetül-Erîbi’n-Nâfia lìr-Rûhânî ve't-Tabîb, Süleymaniye Manuscript Library, MS Nuruosmaniye n. 3466.

Hezarfenn Hüseyin: Tuhfetül-Erîbi’n-Nâfia lìr-Rûhânî ve't-Tabîb, Süleymaniye Manuscript Library, MS Şehit Ali Paşa nr. 2086. 
Marsigli, Luigi Ferdinando: Stato militare dell'Imperio Ottomanno, incremento et decremento del medesimo: L'Etat militaire de l'Empire Ottoman, ses progrès et sa décadence, The Hague, 1732.

Marsigli, Luigi Ferdinando: Bevanda asiatica, brindata all'eminentissimo Buonvisi, Nunzio Apostolico, Vienna: Van Ghelen, 1685.

Marsigli, Luigi Ferdinando: Ragguaglio della Schiavitú, ed. Bruno Basile, Roma: Salerno Editrice, 1996.

Parkinson, John: Theatrum Botanicum, London, 1640.

Pococke, Edward: The Nature of the Drink Kauhi, or Coffe, and the Berry of which it is Made, Described by an Arabian Phisitian, Oxford: Henry Hall, 1659.

Redi, Francesco: Bacco in Toscana, Firenze, 1685.

\section{Secondary Sources}

Bevilacqua, Alexander: The Republic of Arabic Letters: Islam and the European Enlightenment, Cambridge, Mass.: Harvard University Press, 2018.

Bisaha, Nancy: Creating East and West: Renaissance Humanists and The Ottoman Turks, Philadelphia: University of Pennsylvania Press, 2006.

Cowan, Brian: The Social Life of Coffee: The Emergence of the British Coffeehouse, New Haven: Yale University Press, 2005.

Daston, Lorraine (ed.): Biographies of Scientific Objects, Chicago: University of Chicago Press, 2000.

Debus, Allen G.: The Chemical Philosophy: Paracelsian Science and Medicine in the Sixteenth and Seventeenth Centuries, New York: Science History Publications, 1977.

Debus, Allen G.: Man and Nature in the Renaissance, Cambridge University Press, 1978.

Demirhan Erdemir, Ayşegül: "Dâvûd-i Antâkî”, TDV İslâm Ansiklopedisi, IX, 1994, s. 26-27.

Dew, Nicholas: Orientalism in Louis XIV's France, Cambridge: Cambridge University Press, 2009.

Egmond, Florike: The World of Carolus Clusius: Natural History in The Making, 15501610 (London: Pickering \& Chatto, 2010.

Emami, Farshid: "Coffehouses, Urban Spaces, and the Formation of a Public Sphere in Safavid Isfahan," Muqarnas 33 no. 1 (2016): 177-220.

Gherardi, Raffaella (ed.): La Politica, La Scienza, Le Armi: Luigi Ferdinando Marsili e la costruzione della frontier dell'Impero e dell'Europe, Bologna: CLUEB, 2010.

Habermas, Jürgen: The Structural Transformation of the Public Sphere: An Inquiry into a Category of Bourgeois Society, trans. Thomas Burger, Cambridge: MIT Press, 1989. 
Hamilton, Alastair, and Francis Richard: André du Ryer and Oriental Studies in Seventeenth-Century France, Oxford: Oxford University Press, 2004.

Haskell, Yasmin: "Poetry or Pathology? Jesuit Hypochondria in Early Modern Naples," Early Science and Medicine 12 (2007), 187-213.

Hattox, S. Ralph: Coffee and Coffeehouses: The Origins of a Social Beverage in the Medieval Near East, Seattle: WA, 1985.

Hershenzon, Daniel: "Towards a connected history of bondage in the Mediterranean: Recent trends in the field," History Compass, 15 (2017), 1-13.

Ihsanoğlu, Ekmeleddin (ed.): Türkiye Kütüphaneleri İslami Tip Yazmaları Kataloğu Arapça, Türkçe ve Farsça, İstanbul: IRCICA, 1984.

Ihsanoğlu, Ekmeleddin (ed.): Osmanlı Tıbbî Bilimler Literatürü Taribi, İstanbul: ISAR, 2008.

Kafadar, Cemal: "How dark is the history of the night, how black the story of coffee, how bitter the tale of love: The changing measure of leisure and pleasure in early modern Istanbul," Medieval and Early Modern Performance in the Eastern Mediterranean, eds. Arzu Öztürkmen and Evelyn Birge Vitz, Turnhout: Brepols, 2014, 243-269.

Karababa Eminegül, and Güliz Ger: "Early modern Ottoman coffeehouse culture and the formation of the consumer subject," Journal of Consumer Research 37.5 (2010): 737-760.

Küçük, Harun: "New Medicine and the Hikmet-i Tabi'iyye Problematic in Eighteenth Century Istanbul," Texts in Transit in the Medieval Mediterranean, eds. Tzvi Langermann and Robert Morrison, University Park, PA: Penn State Press, 2016, 222-242.

Landweber, Julia: “'This Marvelous Bean’: Adopting Coffee into Old Regime French Culture and Diet," French Historical Studies, 38 (2015): 193-223.

Lavorini, E.: La schiavitú sotto i tartari e i turchi del generale Luigi Ferdinando Marsigli, Bologna: Zanichelli, 1931.

Liberles, Robert: Jews Welcome Coffee: Tradition and Innovation in Early Modern Germany, Waltham, MA, 2012.

Ménage, V. L.: "Husayn (Huseyn) Efendi, known as Hezārfenn.” Encyclopaedia of Islam, Second Edition, ed. P. Bearman, Th. Bianquis, C.E. Bosworth, E. van Donzel, W.P. Heinrichs, Brill Online, 2016.

Meserve, Margaret: Empires of Islam in Renaissance Historical Thought, Cambridge, Mass.: Harvard University Press, 2008.

Mikhail, Alan: "The Heart's Desire: Gender, Urban Space, and the Ottoman Coffee House," Ottoman Tulips, Ottoman Coffee: Leisure and Lifestyle in the Eighteenth Century, ed. Dana Sajdi, London: I.B.Tauris, 2007, 133-170. 
Molnar, Monica: "Nouva vision degli intellettuali italiani sulla cultura musulmana del Seicento: Giovanni Battista Donado e Luigi Ferdinando Marsigli sulla letteratura e scienza dei Turchi," Nouva Corvina, 24 (2012), 57-70.

Rava, Luigi: Il Conte Marsigli e il Caffé, in Memorie intorno a L. F. Marsili pubblicate nel secondo centenario dalla morte per cura del comitato marsiliano, Bologna: Zanichelli, 1930.

Rossi, Ettore: "il Secondo Centenario della Morte di Luigi Ferdinando Marsigli," Oriente Moderno 8 (1931), 415-424.

Sarı, Nil and M. Bedizel Zülfikar: "The Paracelsian Influence on Ottoman Medicine in the Seventeenth and Eighteenth Centuries," Transfer of Modern Science and Technology to the Muslim World, ed. Ekmeleddin Ihsanoğlu, Istanbul: IRCICA, 1992.

Shefer-Mossensohn, Miri: "An Ottoman Physician and His Social and Intellectual Milieu: The Case of Salih bin Nasrallah Ibn Sallum," Studia Islamica, 1 (2011): 133-58.

Siraisi, Nancy G.: Medieval \& Early Renaissance Medicine: An Introduction to Knowledge and Practice, Chicago: University of Chicago Press, 1990.

Spary, Emma: Eating the Enlightenment: Food and the Sciences in Paris, 1650-1760, Chicago: Chicago University Press, 2012.

Stoye, John: Marsigli's Europe 1680-1730: The Life and Times of Luigi Ferdinando Marsigli, Soldier and Virtuoso, New Haven \& London: Yale University Press, 1994.

Tokat, Feyza: Hezarfen Hüseyin Efendinin “Tuhfetül-Erîbi’n-Nâfia lirr-Rûhânî vèt-Tabîb”i, (PhD Diss., Pamukkale University, 2012).

Varni, Angelo (ed.): La Scienza delle Armi: Luigi Ferdinando Marsili 1658-1730, Bologna: Edizioni Pendragon, 2012.

Voigt, Lisa: Writing Captivity in the Early Modern Atlantic: Circulations of Knowledge and Authority in the Iberian and English Imperial Worlds, Chapel Hill: The University of North Carolina Press, 2009.

Wurm, Heidrun: Der Osmanische Historiker Huseyn b. Gafer, genant Hezârfenn, und die Istanbuler Gesellschaft in der zweiten Hälfte des 17. Jahrhunderts. Freiburg: Klaus Schwarz, 1971. 